\title{
Genotypic Correlation Co-efficients among Growth and Root Parameters in Radish Genotypes (Raphanus sativus L.)
}

\author{
V.R. Roopa*, H.P. Hadimani, C.N. Hanchinamani, M.H. Tatagar, Sandhyarani Nishani \\ and Chandrakanth Kamble
}

\author{
Department of Vegetable Science, K. R. C. College of Horticulture, Arabhavi - 591218 , \\ Karnataka, India \\ *Corresponding author
}

\section{A B S T R A C T}

\section{Keywords}

Raphanus sativus L, Correlation, Coefficients and genotypes

Article Info

Accepted:

06 August 2018

Available Online:

10 September 2018
In the present investigation, root yield per hectare had significant and positive correlations with leaf area, root diameter, root length, root to leaf ratio and root weight both at genotypic and phenotypic level. The trait root diameter was significantly and positively correlated with root length, root to leaf ratio, root weight and root yield per hectare whereas, root length had positive and significant correlation with root to leaf ratio, root weight and root yield per hectare at both genotypic and phenotypic level. Positive and significant correlation was observed for root to leaf ratio with root weight and root yield per hectare at both genotypic and phenotypic level.

\section{Introduction}

Radish (Raphanus sativus L.) is ancient and popular root vegetable crop commonly known as mooli in hindi and moolangi in kannada and it belongs to the family cruciferae which is eaten as raw or in cooked form. It is grown for fleshy roots and leaves in both tropical and temperate climate. The edible portion of radish is swollen root that develops from primary root and hypocotyl. It is a rich source of Vit-C (ascorbic acid), calcium and minerals.

In India, it was cultivated maximum in states of West Bengal, Bihar, Uttar Pradesh, Punjab,
Haryana, Gujarath, Himachal Pradesh, Karnataka (Anon. 2017). Its consumption prevents constipation, increases appetite and useful for curing jaundice, liver disorders and also useful in urinary complaints and piles (Dhananjaya, 2007). In homeopathy, it is used for curing chronic diarrhea, headache and sleeplessness.

As most of the traits of economic importance are complex involving several related traits, the knowledge of correlation between these traits is important (Robinson et al., 1951). The association between two variables which can be directly observed is termed as phenotypic correlation. Phenotypic correlation fails to 
give the true picture of relationship between two characters because along with genetic value it is also influenced by the environment.

Therefore, genotypic correlation is essential for studying the real genetic variation in different characters and the manner in which environmental variation affects the expression of such variation. The genetic improvement in dependent trait can be achieved by applying strong selection to a character which is genetically correlated with the dependent character. Therefore, keeping this point of view, the present study entitled Genotypic Correlation Co-efficients among Growth and Root parameters in radish genotypes (Raphanus sativus L.) was attempted.

\section{Materials and Methods}

The experiment was conducted at Kittur Rani Channamma College of Horticulture, Arabhavi during kharif season of 2017-2018 with thirty genotypes of radish which are presented in Table 1. The experiment was laid out in a Randomized Block Design with two replications.

The seeds were sown at a distance of $30 \mathrm{~cm}$ between row to row and $15 \mathrm{~cm}$ between plants. All the recommended cultural operations were followed and observations were recorded in five randomly selected plants per replication for each genotype for all the characters.

The data was analyzed using INDOSTAT software programme. For the analysis of the data the following statistical methods were exercised, namely analysis of variance, genetic parameters viz., genotypic and environmental variance, environmental coefficient of variation (Burton and De Vane, 1953) and classified (high/medium/low) as described by Sivasubramanian and Mennon (1973).

\section{Results and Discussion}

Correlation studies are used to find out the degree and direction of relationship between two or more variables. Knowledge on degree of association of yield with its components is of great importance, because yield is not an independent character, but it is the resultant of the interactions of a number of component characters in which the plant grow.

Further, each character is likely to be modified by action of genes present in the genotypes of plant and also by the environment and it becomes difficult to evaluate this complex character directly. Therefore, correlation study of yield with its component traits has been executed, to find out the yield contributing traits. In the present study both genotypic and phenotypic correlations were worked out for root yield per hectare and its contributing traits.

In the present experiment, root yield per hectare was significantly and positively correlated with leaf area, root diameter, root length, root to leaf ratio and root weight at both genotypic and phenotypic level (Table 2). Similar trend of results are were observed by Mapari et al., (2009) for number of leaves, root length and days required to harvest; Kumar et al., (2009) for number of leaves, root length, root diameter and root to leaf ratio; Jatoi et al., (2011) for root weight and root diameter; Sivathanu et al., (2014) for root length and root diameter; Mallikarjunrao et al., (2015) for number of leaves, root length, root diameter, root weight; Nagar et al., (2016) for number of leaves and root weight; Naseeruddin et al., (2017) for number of leaves, root diameter and root length.

Since, these yield attributing traits are in appropriate direction, selection for such traits would be more worthwhile in improving the root yield per hectare. 
Leaf area was significantly and positively correlated with root diameter, root length, root weight and root yield per hectare. This indicates leaf area is an important trait as it increases the root yield per hectare.

The similar results are observed by Panwar et al., (2003) for root length, root diameter and root weight.
Root diameter had significant and positive correlation with root length, root to leaf ratio, root weight and root yield per hectare at both genotypic and phenotypic level. It indicates if more the root diameter it increases the root yield per hectare. The quite similar results are observed by Sivathanu et al., (2014) for root yield/ha; Mallikarjunrao et al., (2015) for root weight and root to leaf ratio.

Table.1 List of radish genotypes used in the experiment

\begin{tabular}{|c|c|c|}
\hline Sl. No. & Genotype & Source \\
\hline 1 & HRESB-6 & HRES, Hidkal Dam \\
\hline 2 & HRESB-7 & HRES, Hidkal Dam \\
\hline 3 & HRESB-8 & HRES, Hidkal Dam \\
\hline 4 & HRESB-9 & HRES, Hidkal Dam \\
\hline 5 & HRESB-10 & HRES, Hidkal Dam \\
\hline 6 & HRESB-11 & HRES, Hidkal Dam \\
\hline 7 & HRESB-15 & HRES, Hidkal Dam \\
\hline 8 & HRESB-16 & HRES, Hidkal Dam \\
\hline 9 & HRESB-17 & HRES, Hidkal Dam \\
\hline 10 & HRESB-18 & HRES, Hidkal Dam \\
\hline 11 & HRESB-19 & HRES, Hidkal Dam \\
\hline 12 & HRESB-22 & HRES, Hidkal Dam \\
\hline 13 & HRESB-24 & HRES, Hidkal Dam \\
\hline 14 & HRESB-29 & HRES, Hidkal Dam \\
\hline 15 & HRESB-30 & HRES, Hidkal Dam \\
\hline 16 & HRESB-32 & HRES, Hidkal Dam \\
\hline 17 & HUB-1 & L C from Karnataka (Kolar) \\
\hline 18 & HUB-2 & L C from Karnataka (Koppal) \\
\hline 19 & White Icicle & YSPHF, Solan (Himachal Pradesh) \\
\hline 20 & VRRAD-26 & IIVR, Varanasi \\
\hline 21 & VRRAD-30 & IIVR, Varanasi \\
\hline 22 & VRRAD-150 & IIVR, Varanasi \\
\hline 23 & VRRAD-202 & IIVR, Varanasi \\
\hline 24 & VRRAD-205 & IIVR, Varanasi \\
\hline 25 & HUB-3 & LC from Punjab(Ludhiana) \\
\hline 26 & Japanese White & YSPHF, Solan (Himachal Pradesh) \\
\hline 27 & DPR-1 & IIVR, Varanasi \\
\hline 28 & Palam Hriday & IIVR, Varanasi \\
\hline 29 & Pusa Himani & YSPHF, Solan (Himachal Pradesh) \\
\hline 30 & Arka Nishant & IIHR, Banglore \\
\hline
\end{tabular}


Table.2 Genotypic correlation coefficients among growth and root parameters in radish

\begin{tabular}{|c|c|c|c|c|c|c|c|c|}
\hline & 1 & 2 & 3 & 4 & 5 & 6 & 7 & 8 \\
\hline $\begin{array}{l}1 \\
2 \\
3 \\
4 \\
5 \\
5 \\
6 \\
7 \\
8\end{array}$ & 1.00 & $\begin{array}{c}-0.2214 \\
\mathbf{1 . 0 0}\end{array}$ & $\begin{array}{c}0.0142 \\
0.3907^{* *} \\
\mathbf{1 . 0 0}\end{array}$ & $\begin{array}{c}0.0320 \\
0.4904^{* *} \\
0.4281 * * \\
\mathbf{1 . 0 0}\end{array}$ & $\begin{array}{c}0.1605 \\
0.1047 \\
0.7759 * * \\
0.4015 * * \\
\mathbf{1 . 0 0}\end{array}$ & $\begin{array}{c}0.2189 \\
0.4616 * * \\
0.8323 * * \\
0.5959 * * \\
0.8262 * * \\
\mathbf{1 . 0 0}\end{array}$ & $\begin{array}{c}-0.0127 \\
0.1624 \\
0.0367 \\
0.1932 \\
0.2006 \\
0.0283 \\
\mathbf{1 . 0 0}\end{array}$ & $\begin{array}{c}0.219 \\
0.4616 * * \\
0.8323 * * \\
0.5959 * * \\
0.8262 * * \\
1.00 * * \\
0.0283 \\
1.00\end{array}$ \\
\hline & $\begin{array}{l}\text { Critical } \\
\text { cent pro } \\
1 . \\
2 . \\
3 . \\
4 . \\
5 . \\
6 . \\
7 . \\
8 .\end{array}$ & $\begin{array}{l}\mathrm{r}_{\mathrm{g}} \text { value }(5 \%)= \\
\text { bability level, } \mathrm{r} \\
\text { Number of lea } \\
\text { Leaf area }\left(\mathrm{cm}^{2}\right. \\
\text { Root diameter } \\
\text { Root length (c } \\
\text { Root to leaf ra } \\
\text { Root weight } \\
\text { Days to harve } \\
\text { Root yield/h }\end{array}$ & $\begin{array}{l}254 \quad \text { Cri } \\
\text { ectively. }\end{array}$ & $r_{g}$ value $(19$ & 0.330 & \multicolumn{3}{|c|}{$*$ and $* *$ indicate significant at 5 and 1 per } \\
\hline
\end{tabular}

Root length was significantly and positively correlated with root to leaf ratio, root weight and root yield per hectare both at genotypic and phenotypic level. The similar kind of results are opined by Mallikarjunrao et al., (2015) for root weight, root to leaf ratio and root yield per hectare; Kaur et al., (2017) with root weight, root to leaf ratio and root yield per hectare.

Root to leaf ratio was significantly and positively correlated with root weight and root yield per hectare at both genotypic and phenotypic level. This indicates that while, selecting for high yielding genotypes in radish, varieties with high root to leaf ratio is considerable. The results are in agreement with the results of Kaur et al., (2017) for root weight and root yield per hectare.

Root weight was significantly and positively correlated with root yield per hectare a both genotypic and phenotypic level. This indicates root weight was an important trait while selecting for high yielding genotypes in radish. The results are in line with the results of Mallikarjunrao et al., (2015), Nagar et al., (2016), Kaur et al., (2017).

From the above preceding discussion, it is reasonable that a great deal of success can be achieved in improvement of root yield per hectare by applying selection pressure on leaf area, root diameter, root length, rot to leaf ratio and root weight as these traits had significant and positive correlation with root yield per hectare.

\section{References}

Anonymous, 2017, Indian Horti Database, NHB Haryana. http:www.nhb.gov.

Burton, G. W. and De Vane, E. H., 1953, Estimating heritability in tall Fescue (Festuca arundinacea) from replicated clonal material. Agron. J., 45: 478-481.

Dhananjaya, 2007, Organic studies in radish (Raphanus sativus L.) varieties. M.Sc. (Hort) Thesis, Univ. of Agri. Sci., Dharwad (India).

Jatoi, S. A., Javaid, A., Iqbal, M., Sayal, O. U., Masood, S. and Siddiqui, S.U., 
2011, Genetic diversity in radish germplasm for morphological traits and seed storage proteins. Pakistan J. Bot., 43(5): 2507-2512.

Kaur, N., Singh, R. and Singh, D., 2017, Correlation and path coefficient analysis for yield components and quality traits in Radish (Raphanus sativus L.). Agric. Res. J., 54(4): 484-489.

Kumar, R., Sharma, R. and Kansal, S., 2009, Correlation and path analysis studies in European Radishes (Raphanus sativus L.). Indian J., 36(2): 67-71.

Mallikarjunarao, K., Singh, P. K., Vaidya, A., Das, R. K. and Pradhan, R., 2015, Genotypic correlation and path coefficient analysis of yield and its components in radish (Raphnus sativus L.) under Kashmir valley. Ecology Environ. Conserv., 21: 73-77.

Mapari, A. V., Peshattiwar, P. D., Dod, V. N. and Thorat, A., 2009, Correlation and path analysis study in radish (Raphanus sativus L.). The Asian J. Hort., 4(2):285-288.

Nagar, S. K., Paliwal, A., Tiwari, D., Upadhyay, S., Bahuguna, P., 2016, Genetic variability, correlation and path study in radish under near temperate conditions of Garhwal hills. Int. J. Sci. Res. dev., 4(9): 174- 176.

Naseeruddin, K. H., Singh, V., Pant, S. C. and Rana, D. K., 2017, Association and path correlation studies in radish (Raphanus sativus L.) under valley conditions of Uttarkhand. J. Pharmacogn. Phytochem., 7(1): 2298-2302.

Panwar, A. S., Kashyap A. S. and Baweja H. S., 2003, Correlation between yield and yield parameters in radish (Raphanus sativus L.). Indian J. Hill Farm, 16 (1/2): 53-55.

Robinson, H. F., Comstock, R. E. and Harvey, P. H, 1951, Genotypic and phenotypic correlations in corn and their implications in selection. Agron. J., 43(6): 282-287.

Sivasubramanian, S. and Mennon, M., 1973, Heterosis and inbreeding depression in rice. Madras Agri. J., 60: 1139.

Sivathanu, S., Mohammed, Y. G. and Kumar, S. R., 2014, Seasonal effect on variability and trait relationship in radish. Res. Envir. Life Sci., 7(4): 275278.

\section{How to cite this article:}

Roopa, V.R., H.P. Hadimani, C.N. Hanchinamani, M.H. Tatagar, Sandhyarani Nishani and Chandrakanth Kamble. 2018. Genotypic Correlation Co-efficients among Growth and Root Parameters in Radish Genotypes (Raphanus sativus L.). Int.J.Curr.Microbiol.App.Sci. 7(09): 697-701. doi: https://doi.org/10.20546/ijcmas.2018.709.083 